\title{
Biocorrosion of Mild Steel by SRB: Electrochemical Studies
}

\author{
Inês T.E. Fonseca ${ }^{*}{ }^{,}$, M. José Feio ${ }^{b}$, Ana R. Lino ${ }^{b}$, and Valter L. Rainha ${ }^{a}$ \\ ${ }^{a}$ CECUL, Rua da Escola Politécnica, 58, 1294 LISBOA Codex, Portugal \\ ${ }^{b}$ ITQB, Rua da Quinta Grande, Apartado 127, 2780 OEIRAS, Portugal
}

Received: June 30, 1996; November 13, 1996

\begin{abstract}
Realizaram-se estudos electroquímicos sobre a biocorrosão de aço carbono na presença e ausência de bactérias redutoras de sulfato (SRB) em meios aquosos de lactato/sulfato e lactato/nitrato. Medidas de potencial em circuito aberto revelaram um deslocamento do potencial no sentido dos potenciais mais nobres, em ambos os meios. Contudo, oscilações regulares de potencial foram observadas somente no meio de lactato/sulfato.

As fotografias de SEM revelaram a presença de pites, distribuídas na superfície das amostras em ambos os meios, com pites de pequeno tamanho e de forma mais uniforme no meio de lactato/sulfato, o que está de acordo com os resultados de potencial em circuito aberto. A voltametria cíclica mostrou claramente que as SRBs em meio de lactato/sulfato originam velocidades de dissolução elevadas na região transpassiva, com formação de espécies $\mathrm{Fe}^{3+}$.

Electrochemical studies of the biocorrosion of mild steel in the presence and absence of sulfate reducing bacteria (SRB) grown in lactate/sulfate and lactate/nitrate aqueous media were performed. Open circuit potential measurements revealed a displacement of the potential in the noble direction in both media. However, regular oscillations in the potential were observed only in the lactate/sulfate medium.

SEM micrographs showned pits clearly distributed over the surface of the steel samples exposed to SRB cultures in both media, with small size and more uniform pits in the lactate/sulfate media, in agreement with the open circuit potential data. Cyclic voltammetry clearly shows that the SRBs grown in the lactate/sulfate medium lead to high dissolution rates in the transpassive region with the formation of Fe(III) species.
\end{abstract}

Keywords: biocorrosion, sulfate-reducing bacteria (SRB), mild steel, electrochemical data

\section{Introduction}

The role of micro-organisms on the corrosion of metals has received increasing attention in recent years ${ }^{1-4}$. The presence and activities of micro-organisms can cause serious problems, in industry and military and wherever metals are present in our society.

Sulfate-reducing bacteria, SRB, are an assemblage of bacteria that can grow in anaerobic media by the oxidation of organic nutrients, with sulfate being reduced to $\mathrm{H}_{2} \mathrm{~S}$.

The presence and metabolic activity of sulfate-reducing bacteria on metal surfaces leads to changes in $\mathrm{H}_{2} \mathrm{~S}$ concentration and $\mathrm{pH}$ level influencing the rates and the type of corrosion.
Feio $^{5}$ has studied the growth of Desulfovibrio desulfuricans ATCC 27774 bacteria in lactate/sulfate, as well as in lactate/nitrate media, at $37^{\circ} \mathrm{C}$, in the presence of mild steel. From these studies growth curves such as those given in Fig. 1 were obtained. The curves in Fig. 1 show that there is a period in which the bacteria population increases almost exponentially, and after about two days a steady-state of $60 \times 10^{6}$ cells $/ \mathrm{cm}^{2}$ is reached.

In the sulfate medium the metabolic activity of SRB leads to the production of $\mathrm{S}^{2-}$, while in the nitrate medium the reduction process leads to $\mathrm{NH}_{4}{ }^{+}$, according to the mechanism proposed by several authors 6,7 .

Biofilm formation necessarily plays an important role in the corrosion process, but the exact description of the biofilm has not yet been established. Biocorrosion, like 


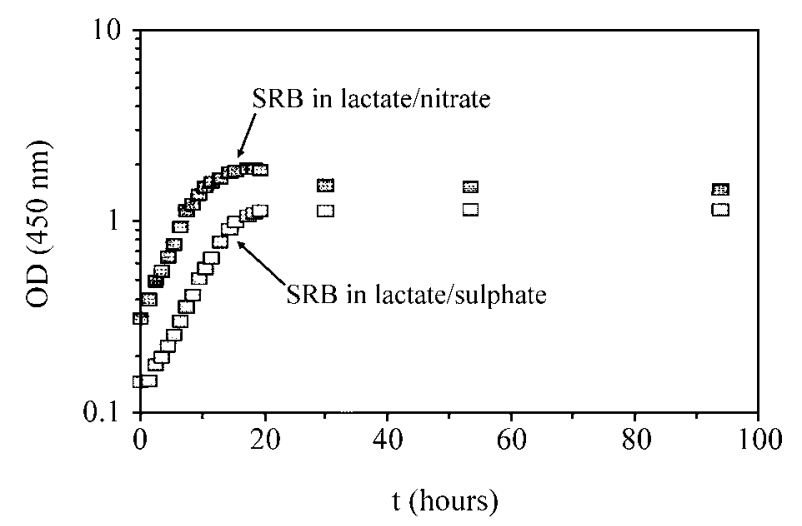

Figure 1. Growth curves of Desulfovibrio desulfuricans ATCC 27774 in lactate/sulfate and lactate/nitrate media 5.

many other corrosion processes, is essentially due to electrochemical reactions; therefore electrochemical techniques are necessarily good tools to evaluate, monitor, and understand biocorrosion both in field and laboratory studies. Extensive electrochemical studies of mild steel samples exposed to the bacteria cultures of Desulfovibrio desulfuricans ATCC 27774, in either the lactate/sulfate or the lactate/ nitrate medium, have been performed in our laboratory ${ }^{8-10}$.

Cyclic voltammograms (CVs), open circuit potential curves, and redox potentials of mild steel in lactate/sulfate and lactate/nitrate media will be reported in this paper.

Electrochemical data is complemented with scanning electron micrographs and other techniques.

\section{Materials and Methods}

Studies were performed with pure cultures of the strain Desulfovibrio desulfuricans ATCC 27774, grown in a lactate/sulfate or a lactate/nitrate medium with the composition as given in Table 1. The media were prepared by sequential addition of the compounds to pure water. The $\mathrm{pH}$ was adjusted to 7.6 after deaeration with pure nitrogen, and the solutions were sterilized at $120^{\circ} \mathrm{C}$ for $30 \mathrm{~min}$. Inoculates were made at $10 \%$ (v:v) injections of steady-state (1 day) cultures.

Steel samples were made from steel with the nominal composition given in Table 2.

All experiments were performed at $37{ }^{\circ} \mathrm{C}$ (optimum growth temperature for the strain under study).

The open circuit potential of each system was measured against a commercial saturated calomel electrode from Radiometer $^{\circledR}$, model K401. The reference electrode was placed in a separate compartment, connected to the main solution by a $\mathrm{KNO}_{3}$ salt bridge. The working electrode, a $0.2 \mathrm{~cm}^{2}$ mild steel disk was pre-treated, as described above.

A HP ${ }^{\circledR} 34401$ A digital multimeter connected by an interface RS-232 to an IBM ${ }^{\circledR}$ PC model 80286, allowed automatic data acquisition at short enough intervals to assume a
Table 1. Chemical composition of the lactate/nitrate and lactate/sulphate media.

\begin{tabular}{ll}
\hline Lactate/Nitrate medium & \\
\hline Compounds & Amounts / $1000 \mathrm{~mL}$ \\
\hline $\mathrm{NH} 4 \mathrm{Cl}$ & $2 \mathrm{~g}$ \\
$\mathrm{MgCl}_{2} \cdot 6 \mathrm{H}_{2} \mathrm{O}$ & $2 \mathrm{~g}$ \\
$\mathrm{~K}_{2} \mathrm{HPO}_{4}$ & $0.5 \mathrm{~g}$ \\
$\mathrm{NaNO}_{3}$ & $2.4 \mathrm{~g}$ \\
$\mathrm{FeCl}_{2} .4 \mathrm{H}_{2} \mathrm{O}$ & $0.007 \mathrm{~g}$ \\
$\mathrm{CaCl}_{2}$ & $0.20 \mathrm{~g}$ \\
$\mathrm{Mineral} \mathrm{complement}_{\mathrm{Sodium} \text { Lactate } 60 \%(\mathrm{w} / \mathrm{w})}$ & $12.5 \mathrm{~mL}$ \\
Yeast extract & $1 \mathrm{~g}$ \\
Cysteine & $0.25 \mathrm{~g}$ \\
\hline
\end{tabular}

\section{Lactate/Sulphate medium}

\begin{tabular}{ll} 
Compounds & Amounts / $1000 \mathrm{~mL}$ \\
\hline $\mathrm{NH}_{4} \mathrm{Cl}$ & $2 \mathrm{~g}$ \\
$\mathrm{MgSO}_{4} .7 \mathrm{H}_{2} \mathrm{O}$ & $2 \mathrm{~g}$ \\
$\mathrm{~K}_{2} \mathrm{HPO}_{4}$ & $0.5 \mathrm{~g}$ \\
$\mathrm{Na}_{2} \mathrm{SO}_{4}$ & $4 \mathrm{~g}$ \\
$\mathrm{FeSO}_{4} .9 \mathrm{H}_{2} \mathrm{O}$ & $0.010 \mathrm{~g}$ \\
$\mathrm{CaCl}_{2}$ & $0.20 \mathrm{~g}$ \\
$\mathrm{Na}_{2} \mathrm{~S} .9 \mathrm{H}_{2} \mathrm{O}$ & $0.25 \mathrm{~g}$ \\
$\mathrm{Wolfe}_{\text {m minerals }}$ & $1 \mathrm{~mL}$ \\
Sodium Lactate $60 \%(w / w)$ & $12.5 \mathrm{~mL}$ \\
Yeast extract & $1 \mathrm{~g}$ \\
Cysteine-HCl & $0.25 \mathrm{~g}$ \\
\hline
\end{tabular}

Table 2. Nominal chemical composition of mild steel (\% p/p).

\begin{tabular}{llllll}
\hline Fe & C & S & Si & Mn & P \\
Bal. & 0,71 & 0,015 & 0,30 & 0,50 & 0,020 \\
\hline
\end{tabular}

quasi-continuous measurement. For the measurements in the bacteria cultures, inoculation was made at time $\mathrm{t}=0$.

Potentiodynamic curves were run with a PARC waveform generator, model 173, coupled to a PARC potentiostat, model 178 and recorded on an x-y recorder from Philips, model PM 8120.

A conventional three-electrode two-compartment glass cell was used. The secondary electrode was a long helix of $\mathrm{Pt}$ wire and the reference was a commercial saturated calomel electrode $\left(\mathrm{E}^{0}=0.242 \mathrm{~V} v s\right.$. SHE).

Before each run the working electrode $\left(\mathrm{a} 0.2 \mathrm{~cm}^{2}\right.$ mild steel disk) was polished when necessary, and then washed and dried. 


\section{Results and Discussion}

\section{Open circuit potential measurements}

The open circuit potential, $\mathrm{E}_{\text {ocp }}$, of mild steel in the various media under study was followed and stored over $50 \mathrm{~h}$ of exposure. The corresponding $\mathrm{E}_{\mathrm{ocp}} v s$. time curves are given in Fig. 2.

During the first $20 \mathrm{~h}$ of exposure in the absence of the bacteria culture the $E_{\text {ocp }}$ kept an almost constant value of -600 and $-625 \mathrm{mV} v$ s. SCE in the lactate/nitrate and the lactate/sulfate media, respectively. Thereafter, in the lactate/nitrate medium, $E_{\text {ocp }}$ is slightly displaced in the negative direction (-600 to -625), while in the lactate/sulfate medium a slight displacement in the positive direction was observed ( -625 to $-600 \mathrm{mV}$ vs. SCE). The presence of a SRB culture in the lactate/nitrate medium leads to a slight displacement of the potential in the negative direction during the first $5 \mathrm{~h}$, followed by a rapid increase in the positive direction from -650 to $-400 \mathrm{mV} v s$. SCE. In the lactate/sulfate medium with the SRB the $\mathrm{E}_{\text {ocp }}$ also varies from -600 to $-400 \mathrm{mV}$ vs. SCE, but at a slower rate, over $20 \mathrm{~h}$ of exposure. Thereafter, strong and regular oscillations in the $\mathrm{E}_{\mathrm{ocp}}$ values are observed, the average value being on the order of $-0.389 \pm 0.009 \mathrm{~V} v s$. SCE. On the other hand, in the lac-

(a)

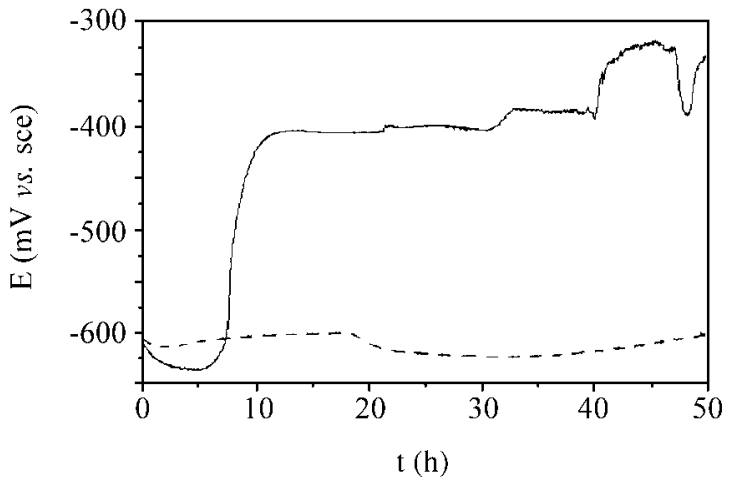

(b)

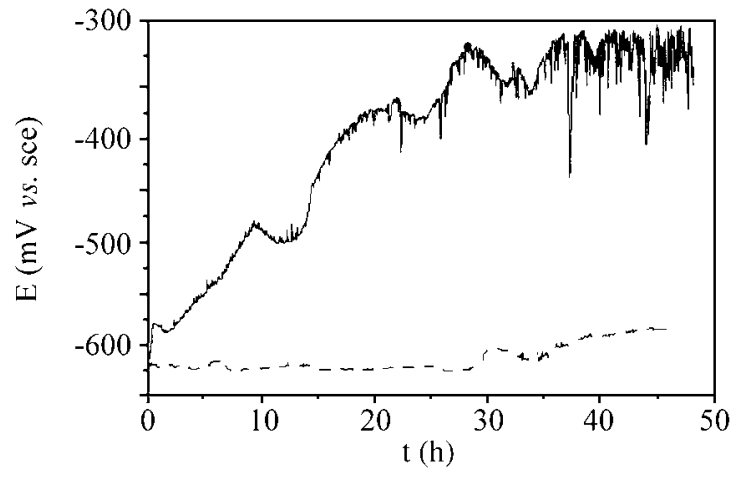

Figure 2. Open circuit potential curves of mild steel in the (a) lactate/nitrate and in (b) the lactate/sulfate media, in the absence (- - ) and presence $(-)$ of a SRB culture. tate/nitrate medium with SRB, large ( -400 to $-300 \mathrm{mV})$ and long $(5 \mathrm{~h})$ oscillations are observed between 40 and $50 \mathrm{~h}$ of exposure.

The results of the $E_{\text {ocp }}$ measurements showed that in both culture media (lactate/nitrate and lactate/sulfate) the SRB lead to a significant displacement of the corrosion potential in the positive direction. This ennoblement may be due to the formation of a passive film, the kinetics of which are fast in the lactate/nitrate medium. The strong oscillations in the $\mathrm{E}_{\text {ocp }}$ after long exposures are also indicative of the onset of localized corrosion, i.e., pitting due to the local rupture or dissolution of the passive film. Videla ${ }^{11}$ has demonstrated that the passive film formed under active SRB biofilm may lead to a pitting attack of steel. However, a definitive interpretation of the results cannot be obtained based only on these measurements. Results need to be complemented by additional data, such as redox potential measurements and resistance polarization measurements.

The ennoblement does not directly demonstrate an increase in the resistance to corrosion. It may be due to kinetic effects, thermodynamic effects, or both. On the other hand, the ennoblement may be related not only to the anodic reaction, but also to changes in the cathodic properties of the sample as a result of the microbial activity on the surface.

\section{Redox potential measurements}

Table 3 gives the redox potentials obtained for the various media under study.

In both cases, the redox potentials indicate, in agreement with other data, an increase in the aggressivity of the medium due to the presence of a bacterial culture.

The difference observed between the redox potentials of both sterile media may be explained by the fact that the lactate/sulfate medium has been poisoned which sulfide (see Table 1) added to ensure a very reducing environment, while in the lactate/nitrate medium the bacterial growth is ensured only by deaeration.

The redox potentials in the presence of SRB in both media present about the same value ( $-450 \mathrm{mV}$ vs. SCE)

\section{Cyclic voltammetry}

Cyclic voltammetric experiments were performed for mild steel immersed in the various media under study. Typical CVs recorded at $20 \mathrm{mV} / \mathrm{s}$ are given in Fig. 3. The CVs show clearly no effects due to the SRB in the lactate/nitrate medium between -1.5 and $-0.4 \mathrm{~V} v s$. SCE. At the upper potential limit of about $-0.4 \mathrm{~V} v s$. SCE a decrease in the anodic transpassive current due to SRB is clearly visible. In any case the cathodic side of the CV shows only one peak located around $-1.0 \mathrm{~V} v s$. SCE.

Completely different behavior is observed in the lactate/sulfate medium. Both the anodic and the cathodic sides 
of the CVs are influenced by the presence of SRB. The charge in the voltammetric curve increases over the entire

Table 3. Redox potentials for the various media under study.

\begin{tabular}{ll}
\hline Medium & $\mathrm{E}_{\text {redox }}(\mathrm{mV} v$ s. SCE) \\
\hline Lactate/nitrate & -167 \\
SRB in lactate/nitrate & -479 \\
Lactate/sulfate & -362 \\
SRB in lactate/sulfate & -444 \\
\hline
\end{tabular}

(a)

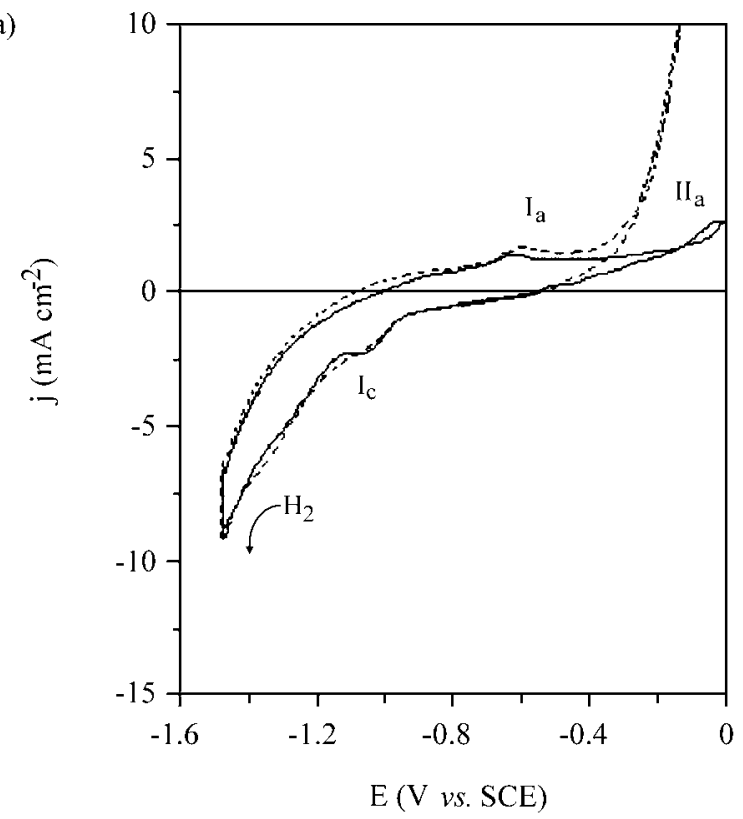

(b)

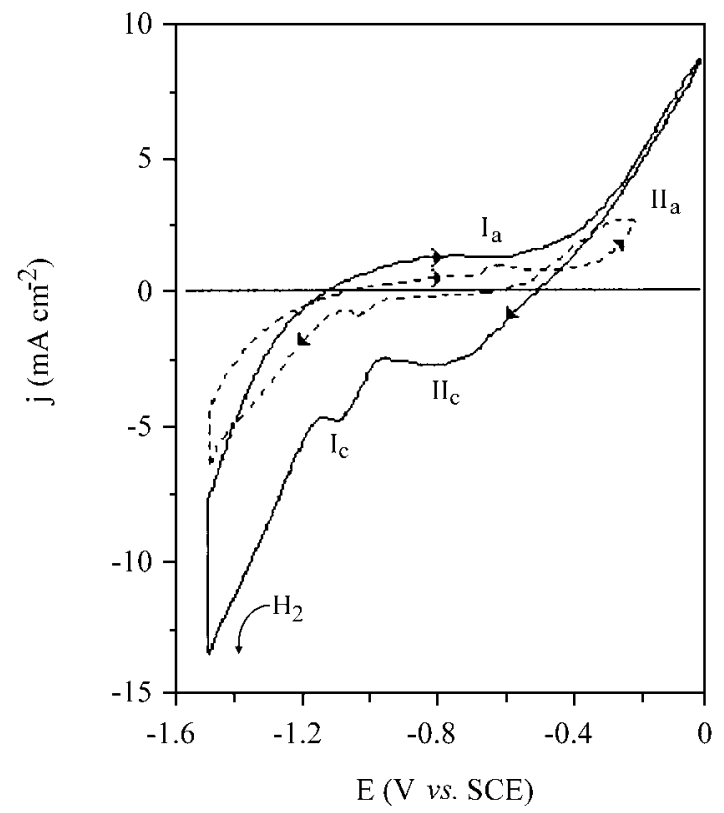

Figure 3. Typical CVs of mild steel in (a) lactate/nitrate and (b) lactate/sulfate media, in the absence (- - ) and presence (-) of a SRB culture. potential polarization region ( -1.5 to $0 \mathrm{~V} v s$. SCE), the effect being particularly strong in the transpassive region (at about $-0.4 \mathrm{~V}$ vs. SCE). Two cathodic peaks are observed at -0.65 and $-1.0 \mathrm{~V} v s$. SCE, while in the absence of SRB, only the cathodic peak around $-1.0 \mathrm{~V}$ vs. SCE was recorded. This is a clear indication that SRB in the lactate/sulfate medium lead to the formation of Fe(III) species whenever polarizations higher than $-0.4 \mathrm{~V}$ are applied. $\mathrm{The}_{2} \mathrm{H}_{2}$ evolution reaction is also strongly catalyzed by SRB in the lactate/sulfate medium.

Under the experimental conditions of Fig. 3, an hysteresis loop in the reverse scan is observed for both base cultural media (lactate/nitrate and lactate/sulfate) in the absence of SRB and also in their presence, but in this case only in the lactate/nitrate medium. The crossover (hysteresis loop) is an indication of the onset of localized corrosion of the base metal (the formation of pits nucleating the base metal after or simultaneous with the local dissolution of the passivating film).

The occurrence of pitting in the absence of SRB is most probably due to the amount of $\mathrm{Cl}^{-}$in the mineral base media (see Table 1). The high transpassive currents observed with the bacteria culture in the lactate/sulfate medium, shown in Fig. 3(b), clearly indicate the high aggressivity of the medium induced by the microbial activity of the SRB culture in the lactate/sulfate medium, most probably due to changes in $\mathrm{pH}$ (production of organic or mineral acids), leading to the electrochemical dissolution of the passivating film.

Pitting has been confirmed by SEM micrographs (see Fig. 4). Figure 4 shows micrographs of the mild steel samples after 21 days of exposure in the lactate/sulfate and the lactate/nitrate media in the presence of SRB (after biofilm and corrosion products removal).

The photomicrographs given clearly show pits distributed over the surface of the steel samples exposed to SRB cultures in both media; however the pits of the exposed samples in the lactate/sulfate medium are small and more uniform in shape, in agreement with open circuit potential data.

\section{Concluding Remarks}

The presence of SRB shifts the corrosion potential to more positive values, but introduces oscillations indicative of localized corrosion; the potential oscillations are particularly well defined and regular in samples exposed to SRB grown in the lactate/sulfate medium.

Without sulfate the results in the sterile medium and in the SRB culture are similar, while in its presence their strong influence is well demonstrated: the reduction of $\mathrm{SO}_{4}{ }^{2-}$ to $\mathrm{S}^{2-}$ or $\mathrm{H}_{2} \mathrm{~S}$ is a key process in $\mathrm{SRB}$-induced corrosion. 


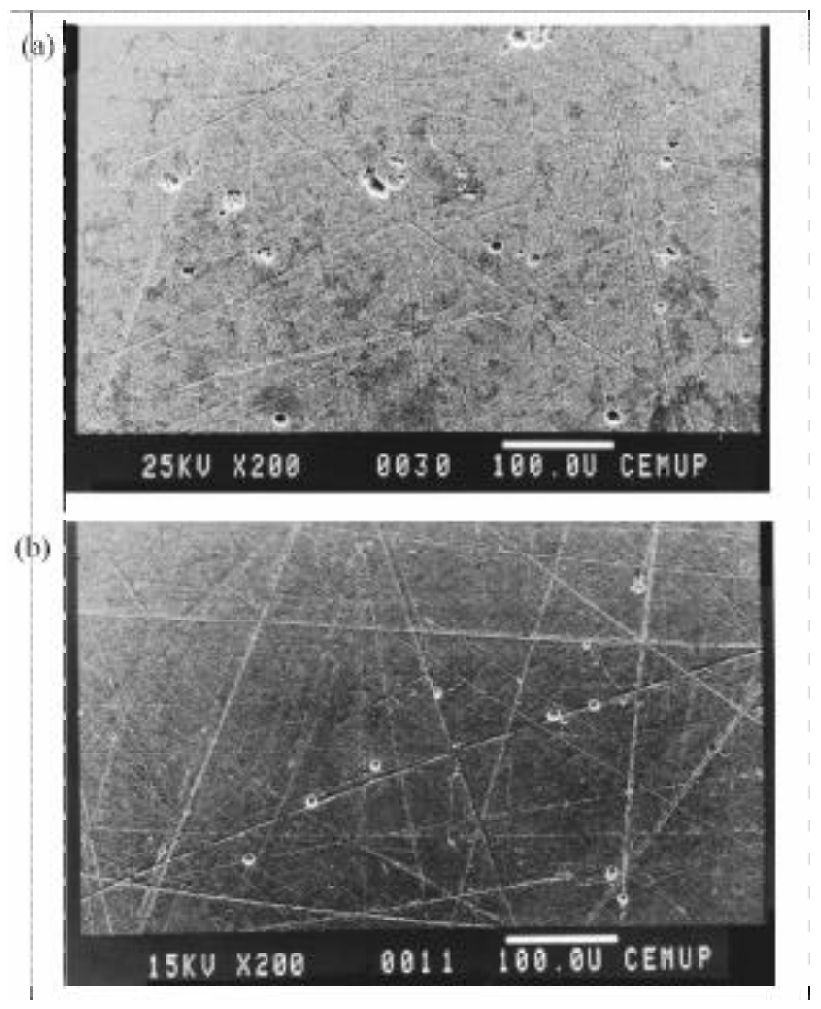

Figure 4. Micrographs of mild steel samples after 21 days of exposure to: (a) lactate/sulfate or (b) lactate nitrate medium, after removal of biofilm and corrosion products.

The establishment of a mechanism for the anaerobic corrosion of mild steel in a SRB culture in either a lactate/nitrate or lactate/sulfate medium requires complementary studies, e.g., cell-counting, bacteria activity, hydrogenase activity, depletion of nitrate, sulfate and lactate, $\mathrm{H}_{2} \mathrm{~S} / \mathrm{S}^{2-}$ and $\mathrm{pH}$ evaluations, etc. Some of these studies are in progress, and with them we expect to be able to correlate some of the variables and to make contributions in order to support mechanisms already proposed.
The use of other electrochemical techniques, namely, microelectrodes, split-cells and noise analysis, may also lead to useful data, particularly when localized corrosion is involved.

\section{Acknowledgments}

V.R. thanks the Junta Nacional de Investigação Científica e Tecnológica (JNICT) for a fellowship (FMRH/ BIC/1394/94).

The authors thank JNICT (EUREKA-CAMICO project 1121 and CECUL Unidade I \& D 301/94) for financial support. The support of Grace Dearborn (Water Systems) is also acknowledged.

Thanks are also due to Prof. J.J.G. Moura for helpful suggestions and comments.

\section{References}

1. Iverson, W.P. Adv. Appl. Microbiol. 1987, 32, 1.

2. Edyvean, R.G.J.; Videla, H.A. Interdis. Sci. Rev. 1981, 16, 267.

3. Sand, W. Werkstoffe und Korrosion 1994, 45, 10.

4. Lee, W.; Lewandowski, Z.; Nielsen, P.H.; Hamilton, W.A. Biofouling 1995, 8, 165.

5. Feio, M.J. In Biocorrosão: Mecanismo e Controlo; Final year report; FCUL; Lisboa, 1993.

6. Cord-Ruwish, R.; Widell, F. Appl. Microbiol. Biotechnol. 1986, 25, 165.

7. Pankhania, I.P.; Moosavi, A.N.; Hamilton, W.A. J. Gen. Microbiol. 1986, 132, 3357.

8. Rainha, V.L. In Biocorrosão de aços pelas Bactérias Redutoras de Sulfato; Final year report; FCUL; Lisboa, 1994.

9. Fonseca, I.T.E.; Lino, A.R.; Rainha, V.L. In The Proceedings of the 3rd International EFC Workshop; Institute of Materials; London, 1995, p 188.

10. Fonseca, I.T.E.; Lino, A.R.; Feio, M.J.; Rainha, V.L. Corr. e Prot. Mat. 1996, 15, 6.

11. Videla, H.A. In Biological Induced Corrosion, NACE-8; Dexter, S.G. Ed.; Houston, TX, 1985, p 162. 